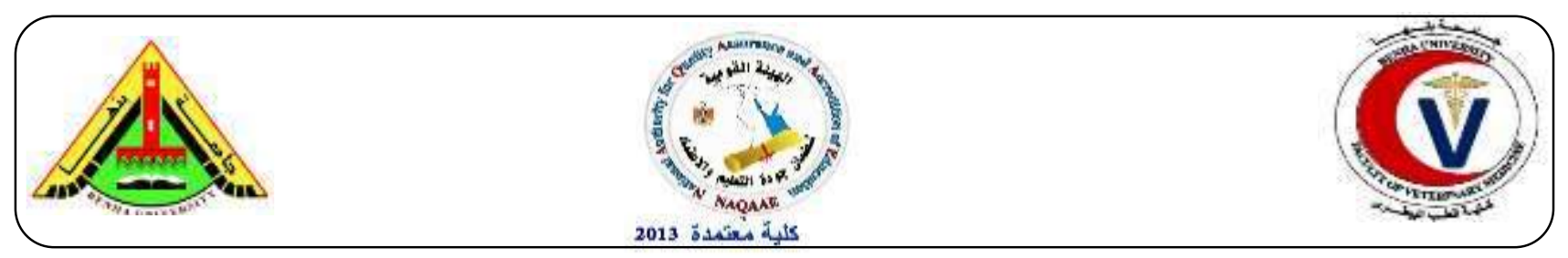

\title{
Diagnostic verification of Brucella species among aborted small ruminants and in-contact persons in Minia governorate
}

\author{
Ashraf A. Abd El Tawab ${ }^{1}$, Fatma I. El-Hofy ${ }^{1}$, Eman Ramadan ${ }^{2}$, Sara Refaat ${ }^{1}$ \\ ${ }^{1}$ Department of Bacteriology, Immunology and Mycology, Faculty of Veterinary Medicine, Benha University \\ ${ }^{2}$ Department of Reproductive Diseases Research, Animal Reproduction Research Institute, Al-Haram, Giza, Egypt
}

\section{A B S T R A C T}

In the current study, a total of 50 sheep, 23 goat and 60 human blood serum samples were collected for serological tests. A total of 30 (22 ewes and 8 does) milk samples, 43(25 ewes and 18 does) vaginal swabs, 14 preputial swabs from rams and 60 human citrated plasma were collected for bacteriological and molecular studies. All examined sheep and goat were non-vaccinated. Ewes and does had history of abortion, while rams had no clinical signs. Samples were collected from different localities at Minia governorate. Serological results using buffered acidified plate antigen test (BAPAT), rose Bengal test (RBT), rivanol test (RT), tube agglutination test (TAT), and indirect enzyme linked immunosorbent assay (iELISA) gave 32(64\%), 30(60\%), 26(52\%), 31(62\%), and $28(56 \%)$ in sheep; respectively, where in goat revealed 23(100\%), 23(100\%), 22(95.7\%), 23(100\%), and $22(95.7 \%)$ respectively. While human serum samples were 33(55\%), 29(48.3\%), 33(55\%), $27(45 \%)$, and 23(38.3\%); respectively. The bacteriological results revealed 35 isolates which were biochemically identified as B. melitensis biovar3 [10 (45.5\%), 4 (50\%), 4(16\%), 10 (55.6\%), 2 $(14.3 \%)$, and $5(8.3 \%)$ ] from ewes' milk samples, does' milk samples, ewes' vaginal swabs, does' vaginal swabs, rams' preputial swabs and human citrated plasma; respectively. All 35 strains were molecularly identified using multiplex polymerase chain reaction (PCR) as B. melitensis. Conclusively, brucellosis was endemic at Minia governorate with a high level especially in goat. Rams act as chronic carriers leading to public health hazards. B. melitensis is the prevalent serotype in Egypt. More effective preventive and control measures should be applied.

Keywords: Brucellosis, Sheep, Goat, Human, Egypt.

Received: 19 June 2019, Accepted: 17 July 2019 (http://www.bvmi.bu.edu.eg) $\quad$ (BVMJ-36(2):66-76, 2019)

\section{INTRODUCTION}

Brucellosis caused by the genus "Brucellae" which are Gram-negative and aerobic facultative intracellular coccobacilli which can infect cattle, sheep, goat, and other livestock animals (Corbel, 1997). The Food and Agriculture Organization (FAO), the World Health Organization (WHO) and the Office
International des Epizooties (OIE) considered brucellosis as one of the widest spread zoonotic diseases of domestic and wild animals throughout the world (Thakur et al., 2003). Moreover, WHO recently estimated that the median global number of foodborne illness cases due to Brucella infection was 
393,239 (Havelaar et al., 2015). The main etiologic agent of brucellosis in small ruminants was B. melitensis which could lead to abortion and reduction of milk production (Corbel, 2006; Hussein et al. 2019).

In Egypt, brucellosis is still endemic in human and animals at most parts of the country. Thus, the epidemiologic situation of the disease is obscure and needs more cultivation and biotyping of Brucella isolates for all governorates to adjust the control programs and to monitor outbreaks (Wareth et al., 2014). The seroprevalence of human brucellosis was mentioned to be as high as $8 \%$ in high-risk populations in Egypt (Samaha et al., 2009). The true incidence of human brucellosis in Egypt couldn't be well estimated as several cases are not informed to the public health authorities. Transmission of brucellosis to humans is strongly referred to contact with infected animals (Ramadan et al., 2019,c).

No single test could be used for serological diagnosis of brucellosis, so a combination of serological tests (BAPAT, RBT, TAT and RT) should be applied for reduction the number of false negative and false positive reactions (Montasser et al., 2011). Moreover, ELISA is more suitable, sensitive and specific test (Fadeel et al., 2006).

In endemic countries, serological tests have to be accompanied with molecular detection and/or culture for the best diagnosis and control (El-Diasty et al., 2018). Nucleic acid amplification methods such as PCR is rapid, sensitive, high specific and can overcome the limitations of conventional detection methods (Elfaki, et al., 2005). Since eradication of the disease needs accurate diagnosis, the aim of the current work is serological, bacteriological and molecular investigation of brucellosis among sheep, goat and human in Minia governorate.

\section{Materials and methods}

\subsection{Collection of samples:}

\section{Animal samples}

A total of 73(50 sheep and 23 goat) blood samples for sera separation were collected for serological tests. A total of 30(22 ewes and 8 does) milk samples, 43(25 ewes and 18 does) vaginal swabs and 14 preputial swabs from rams were collected for bacteriological and molecular studies. All examined sheep and goat were non-vaccinated. Ewes and does had history of abortion, while rams had no clinical signs.

\section{Human samples}

From persons who were in contact with brucellosis suspected sheep and goats, 60 blood samples for sera separation were collected for serological tests and 60 citrated plasma were collected for bacteriological and molecular studies.

\subsection{Serological tests:}

\section{Buffered acidified plate antigen test (BAPAT)} The collected sheep and goat serum samples were examined using BAPA provided by Veterinary Serum and Vaccines Research Institute (VSVRI) (Abbasia Laboratories, Abbasia, Cairo, Egypt). The human serum samples were tested using cromatest which was obtained by LiNEAR (Barcelona, Spain). Any degree of agglutination was considered as positive results (OIE, 2015).

\section{Rose Bengal test (RBT)}

All collected sheep, goat and human serum samples were tested using antigen stained with rose Bengal and buffered to a low $\mathrm{pH}, 3.65 \pm$ 0.05 (IDEXX Laboratories, Pourquier, Hoofddorp, the Netherlands). Any degree of agglutination was considered positive results. The serum samples and antigen were carried at room temperature $\left(22^{\circ} \mathrm{C} \pm 4^{\circ} \mathrm{C}\right)(\mathrm{OIE}, 2016)$.

\section{Tube agglutination test (TAT)}

All tested animal and human serum samples were examined by TAT using $B$. abortus 
concentrated antigen (white antigen) obtained by VSVRI (Abbasia Laboratories, Abbasia, Cairo, Egypt). A visible agglutination at dilution of $1 / 40++$ or more was considered positive (Alton et al., 1988; MacMillan, 1990).

\section{Rivanol test (RT)}

All collected animal and human serum samples were tested by RT using rivanol antigen and solution obtained by VSVRI (Abbasia Laboratories, Abbasia, Cairo, Egypt). A complete agglutination at dilution of $1 / 25++$ or more was considered positive (Alton et al., 1988; MacMillan, 1990).

\section{Indirect enzyme linked immunosorbent assay (iELISA)}

All collected animal and human serum samples were tested with iELISA validated for the detection of anti-Brucella antibodies (SERELISA kit) provided by SYNBIOTICS (Gerland Plaza, Lyon, France), which contained all the necessary reagents. The test was performed according to the manual which was accompanied with the kit (Ekgatat et al., 2010).

\subsection{Bacteriology:}

All collected milk samples, vaginal swabs, preputial swabs from sheep and goat and citrated plasma from human were cultured onto Brucella selective medium and incubated at $37^{\circ} \mathrm{C}$ in condition of $10 \% \mathrm{CO}_{2}$ for 5 days. The suspected colonies were identified biochemically using phenotypical methods (morphology, $\quad \mathrm{CO}_{2}$ requirements, $\quad \mathrm{H}_{2} \mathrm{~S}$ production, urease, catalase and oxidase activity, nitrate reduction, lactose fermentation, citrate utilization, grow in presence of thionine and fuchsin dyes (at different concentrations: $1: 50,000$ and $1: 100,000)$, lysis by Tbilisi phage and agglutination with $\mathrm{A}$ and $\mathrm{M}$ anti-sera) (MacMillan, 1990).

\subsection{Molecular identification:}

All obtained isolated strains were suspected to molecular identification.

\subsubsection{Extraction of crude DNA from bacteria:} DNA template was prepared by boiling according to OIE (2009) centrifuged for 10 min and the supernatants were used as DNA templates for PCR amplification stored at -20 till use.

\subsubsection{Polymerase chain reaction (PCR):}

PCR reaction was performed in a total volume of $25 \mu \mathrm{l}$ with $5 \mu \mathrm{l}$ of the DNA template, 25 pmol of each oligonucleotide primer (Metabion international AG) of Brucella. The primers B4 and B5 were designed to amplify a target sequence of 223-bp within a gene of Brucella cell surface protein (BCSP) code for the production of a $31-\mathrm{kDa}$ membrane protein specific to the genus Brucella. Detailed sequence of the used primer was shown in Table (1). The cycling protocol was as follow: initial denaturation at $95^{\circ} \mathrm{C}$ for $5 \mathrm{~min}$. then 35 cycles of denaturation at $95^{\circ} \mathrm{C}$ for $45 \mathrm{~s}$, annealing at $55^{\circ} \mathrm{C}$ for $45 \mathrm{~s}$, extension at $72^{\circ} \mathrm{C}$ and final extension at $72^{\circ} \mathrm{C}$ for $10 \mathrm{~min}$.

\subsubsection{Multiplex PCR assay:}

The assay was performed according to Bricker and Halling (1994) using a single reverse primer, targeting the Brucella insertion element IS711, and three different forward primers Table (1). The assay was performed using total volume of $50 \mathrm{ul}$ reaction mix contain $5 \mathrm{ul}$ of template DNA, 50 pmol of each primer and $1 \mathrm{X}$ of PCR mix. The cycling protocol was as follow: initial denaturation at $95^{\circ} \mathrm{C}$ for $4 \mathrm{~min}$. then 35 cycles of denaturation at $95^{\circ} \mathrm{C}$ for $1.15 \mathrm{~min}$., annealing at $55^{\circ} \mathrm{C}$ for $1.15 \mathrm{~min}$, extension at $72^{\circ} \mathrm{C}$ for $1.30 \mathrm{~min}$. and final extension at $72^{\circ} \mathrm{C}$ for $10 \mathrm{~min}$.

\subsubsection{Analysis of PCR products:}


The analysis was carried out according to Sambrook et al. (1989) using $1.5 \%$ ethidium bromide stained agarose gel and visualized under ultraviolet trans-illuminator.

\subsection{Statistical analysis:}

Chi-square statistic was used and $(\mathrm{p}<0.05)$ using IBM® SPSS statistic version 20 (SPSS Inc., Chicago, Illinois, USA). NS: Nonsignificant $(\mathrm{P}>0.05)$.

\section{RESULTS}

\subsection{Serological results:}

Results of different used serological tests BAPAT, RBT, RT, TAT, and iELISA revealed 32 (64\%), 30(60\%), 26 (52\%), 31 (62\%), and $28(56 \%)$ in sheep respectively, where in goat gave 23 (100\%), 23 (100\%), 22 (95.7\%), 23 $(100 \%)$, and $22(95.7 \%)$ respectively. While human serum samples were $33(55 \%), 29$ (48.3\%), 33 (55\%), 27 (45\%), and 23 (38.3\%) respectively. Table (2) and Fig. (1)

\subsection{Bacteriological results:}

A Out of 30 (22 ewes and 8 does) milk samples, $10(45.5 \%)$ and $4(50 \%)$ isolates respectively were isolated. Out of 43 (25 ewes and 18 does) vaginal swabs, 4 (16\%) and $10(55.6 \%)$ isolates respectively were isolated. The fourteen rams' preputial swabs revealed 2 $(14.3 \%)$ strains. While the sixty human citrated plasma gave $5(8.3 \%)$ isolates. All isolates were biochemically identified as $B$. melitensis biovar3. Table (3) and Fig. (2)

\subsection{Molecular results:}

The BCSP PCR assay of isolates revealed positive Brucella strains for all 35 isolates (lane 2-36). Lane (2-11) were ewes' milk samples, lane (12-15) were does' milk samples, lane (16-19) were ewes' vaginal swabs, lane (20-29) were does vaginal swabs, lane (30-31) were rams' preputial swabs and lane (32-36) were human citrated plasma. Figure (3). The multiplex PCR of Brucella strains showed that all 35 isolates were positive for $B$. melitensis (lane 3-37). Lane (3-12) were ewes' milk samples, lane (13-16) were does' milk samples, lane (17-20) were ewes' vaginal swabs, lane (21-30) were does vaginal swabs, lane (31-32) were rams' preputial swabs and lane (33-37) were human citrated plasma. Figure (4).

Table 1: The used primers in the study.

\begin{tabular}{llcc}
\hline Target & \multicolumn{1}{c}{ Primer sequence (5 - 3) } & $\begin{array}{c}\text { Amplicon } \\
\text { size }\end{array}$ & Purpose \\
\hline Brucella cell & F:TGGC TCGGTTGCCAATATCAA & 223bp & Identification \\
surface protein & R:CGCGCTTGCCTTTCAGGTCTG & & \\
(BCSP) & Mukherjee et al. (2007) & & \\
B. melitensis & F:AAA TCG CGT CCT TGC TGG TCT GA & 731bp & Multiplex PCR \\
& R:TGC CGA TCA CTT AAG GGC CTT CAT & & \\
B. abortus & F:GAC GAA CGG AAT TTT TCC AAT CCC & 498bp & Multiplex PCR \\
& R:TGC CGA TCA CTT AAG GGC CTT CAT & & \\
& Bricker and Halling (1994); Kumar et al. & & \\
& (2014) & & \\
\end{tabular}


Table 2: The serological incidence of brucellosis in human, sheep and goat using different tests.

\begin{tabular}{ccccccc}
\hline Species & $\begin{array}{c}\text { No. of } \\
\text { examined } \\
\end{array}$ & BAPAT & RBT & RT & TAT & iELISA \\
\cline { 3 - 7 } & $\begin{array}{c}\text { serum } \\
\text { samples }\end{array}$ & & & & & \\
\hline Sheep & 50 & $32(64)^{\mathrm{a}} \mathrm{A}$ & $30(60)^{\mathrm{a}} \mathrm{A}$ & $26(52)^{\mathrm{a}} \mathrm{A}$ & $31(62)^{\mathrm{a}} \mathrm{A}$ & $28(56)^{\mathrm{a}} \mathrm{A}$ \\
Goat & 23 & $23(100)^{\mathrm{a}} \mathrm{B}$ & $23(100)^{\mathrm{a}} \mathrm{B}$ & $22(95.7)^{\mathrm{a}} \mathrm{B}$ & $23(100)^{\mathrm{a}} \mathrm{B}$ & $22(95.7)^{\mathrm{a}} \mathrm{B}$ \\
Human & 60 & $33(55)^{\mathrm{a}} \mathrm{A}$ & $29(48.3)^{\mathrm{a}} \mathrm{A}$ & $33(55)^{\mathrm{a}} \mathrm{A}$ & $27(45)^{\mathrm{a}} \mathrm{A}$ & $23(38.3)^{\mathrm{a}} \mathrm{A}$ \\
\hline
\end{tabular}

BAPAT: Buffered acidified plate antigen test.

RBT: Rose Bengal test.

RT: Rivanol test.

TAT: Tube agglutination test.

iELISA: Indirect enzyme linked immunosorbent assay.

Values with different superscripts in the same rows "differnet tests" are significantly different at least $(\mathrm{P}<0.05)$.

Values with different capital letters in the same columns "different species" are significantly different at least $(\mathrm{P}<0.05)$.

Table 3. The incidence of bacteriological isolation from different collected samples of sheep, goat and human.

\begin{tabular}{cccccc}
\hline \multicolumn{2}{c}{ Milk samples (n=30) } & \multicolumn{2}{c}{ vaginal swabs (n=43) } & $\begin{array}{c}\text { Rams' preputial } \\
\text { swabs (n=14) }\end{array}$ & $\begin{array}{c}\text { Human citrated } \\
\text { plasma (n=60) }\end{array}$ \\
\cline { 1 - 4 } Ewes (22) & Does (8) & Ewes (25) & Does (18) & & Positives (\%) \\
\hline Positives (\%) & Positives (\%) & Positives (\%) & Positives (\%) & Positives (\%) & P(8.3) \\
\hline $10(45.5)^{\mathrm{a}}$ & $4(50)^{\mathrm{a}}$ & $4(16)^{\mathrm{b}}$ & $10(55.6)^{\mathrm{a}}$ & $2(14.3)^{\mathrm{bc}}$ & \\
\hline
\end{tabular}

Values with different superscripts in the same rows are significantly different at least $(\mathrm{P}<0.05)$.

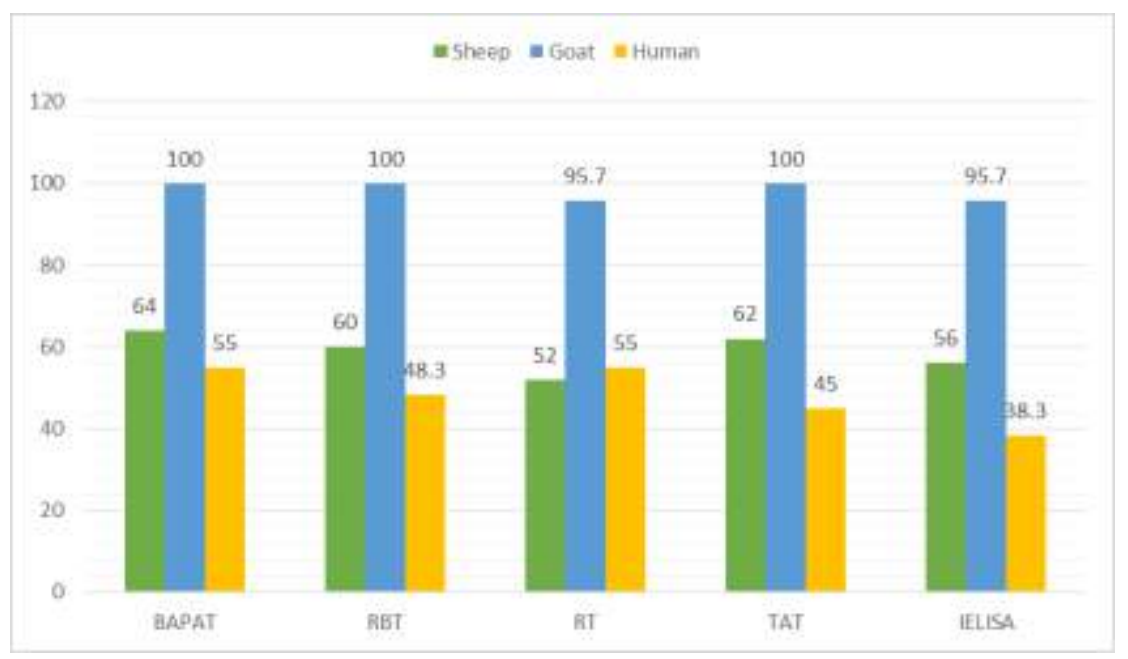

Fig.1. The serological incidence of brucellosis in human, sheep and goat using different tests. 


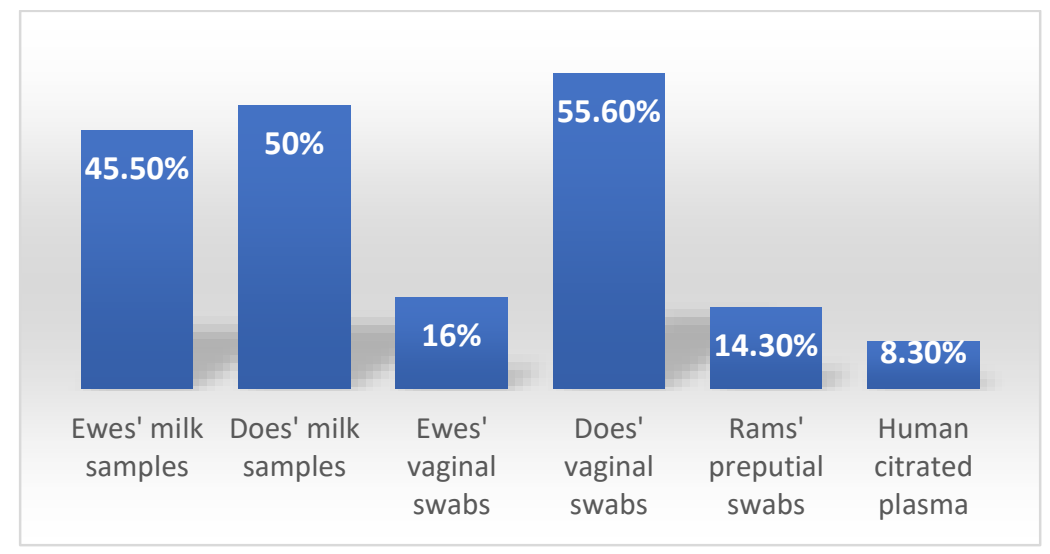

Fig.2. The incidence of bacteriological isolation from different collected samples of sheep, goat and human

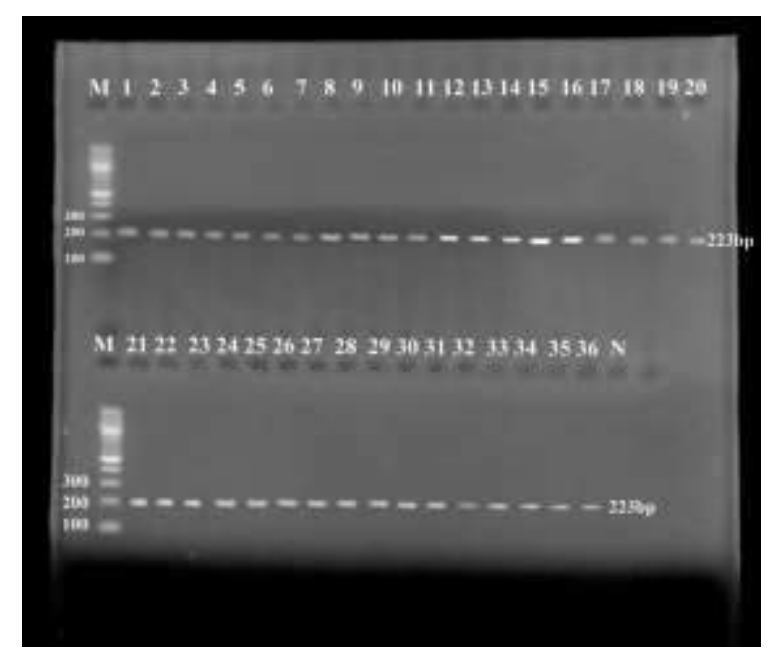

Fig.3. Ethidium bromide stained 1.5\% agarose gel electrophoresis of bcsp PCR assay of isolates. Lane M: 100bp DNA Ladder. Lane (1): Control positive. Lane (2-36): Positive Samples "Brucella strains". Lane N: Control Negative.

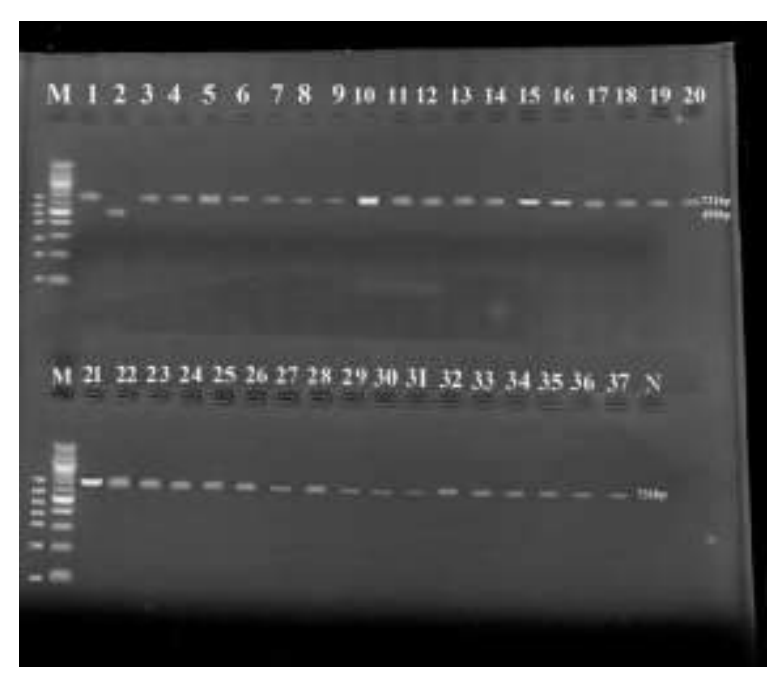

Fig.4. Ethidium bromide stained 1.5\% agarose gel electrophoresis of PCR-amplified IS711 element specific for B. melitensis. The figure shows a specific amplicon of 731-bp DNA. Lane M: 100bp DNA Ladder. Lane (1): Control positive for B. melitensis. Lane (2): Control positive for B. abortus. Lane (3-37): Positive Samples "B. melitensis". Lane N: Control Negative. 


\section{DISCUSSION}

Brucellosis in livestock causes enormous losses for economies and severe public health hazard. This study was run in aborted, nonvaccinated sheep and goats, and in contact persons. The serological results using BAPAT, RBT, TAT, RT and iELISA gave $(64 \%, 60 \%$, $52 \%, 62 \%$ and $56 \%$ ); respectively in sheep, (100\%, 100\%, 95.7\%, $100 \%$ and $95.7 \%$ ); respectively in goat as shown in table (2) and figure (1). The gained results were revealed a high incidence of brucellosis in sheep and goat with the highest significant level in goat $(\mathrm{P}<0.05)$. These results were supported by Abd El-Fatah et al. (2014) who stated the prevalence of brucellosis using BAPAT, RBT and TAT was $61.8 \%$ for all tests in sheep, while in goat was $66.66 \%, 73.33 \%$ and $66.66 \%$; respectively. Moreover, Farghaly et al. (2018) recorded brucellosis percentage of $60 \%$ among aborted ewes and Safaa (2011) reported $32.5 \%$ and $30 \%$ in sheep and goats respectively. Other reports coincided but with lower prevalence where in Assiut governorate Hussein et al. (2019) showed 21, 28\% seropositives in aborted ewes, and Nagati and Hassan (2016) declared $16.4 \%$ and $28.9 \%$ in sheep and goat; respectively. While, Hegazy et al. (2011) found that the seroprevalence of brucellosis in Kafr-Elsheikh governorate was $12.2 \%$ and $11.3 \%$ in sheep and goat respectively.

The discrepancy between obtained and other previous results might be attributed to the variation in degree of infection, virulence of organism, previous exposure and stage of pregnancy affecting the antibody titer which usually reaches the diagnostic level after four weeks from exposure during fourth to sixth month of gestation and at 10 weeks after exposure in non-pregnant or in the first trimester gestation (Nicoletti, 1990). Also, it might be attributed to that current study was applied to aborted non-vaccinated animals (Farghaly et al., 2018).

In the present study, prevalence of human brucellosis using BAPA, RBT, RT, TAT and iELISA was $55 \%, 48.3 \%, 55 \%, 45 \%$ and $38.3 \%$ respectively as shown in table (2) and Figure (1). The gained results agreed with Farghaly et al. (2018) who found that the prevalence of human brucellosis was 56\% among workers who were close in contact with aborted ewes. Additionally, EL-Sayed et al. $(2011, a)$ reported $37.74 \%$ of different occupation, El-Diasty et al. (2016) stated 21\% seropositives, and Ramadan et al. $(2019$,c) who reported seroprevalence reached to $22.22 \%$ among abattoir workers. Otherwise, the current results were higher than that reported by Nagati and Hassan (2016) who found that the seroprevalence of human brucellosis was $15.2 \%$ and Samaha et al. (2009) found that the seroprevalence of human brucellosis was $8 \%$.

Regarding to the variety between results of different used serological tests, the percentages were higher using BAPAT, RBT and TAT than RT and iELISA. These obtained results could be explained by many previous studies which reported that BAPAT, RBT and TAT are more sensitive and less specific, while RT and iELISA are less sensitive and more specific. (Montasser et al., 2011; Ramadan et al., 2014; Ramadan et al., 2019,a).

Bacterial culture is a gold standard with high specificity (Wareth et al. 2014), thus, bacteriological isolation and identification were performed for accurate and confirmative diagnosis of serologically reactive animals. However, some Brucella microorganisms were not yet causing important serologic responses, could be isolated from milk samples and/or other tissues (Nagati and Hassan, 2016). In the present study, bacteriological isolation yielded 35 isolates which were biochemically 
identified as B. melitensis biovar3 [10 (45.5\%), 4 (50\%), 4 (16\%), 10 (55.6\%), 2 (14.3\%), and $5(8.3 \%)$ ] from ewes' milk samples, does' milk samples, ewes' vaginal swabs, does' vaginal swabs, rams' preputial swabs and human citrated plasma respectively as illustrated in Table (3) and Figure (2). Because of Brucella DNA could be detected in pure culture and in clinical specimens (Colmenero et al. 2010), diagnosis and bio typing of Brucella by PCR is more specific than serological tests and more sensitive than culture (Ramadan and Gafer, 2016; Hussein et al., 2019). All obtained 35 isolates in the present study were confirmedly identified as B. melitensis BCSP and multiplex PCR. This finding emphasized that brucellosis is still endemic in Egypt caused mainly by $B$. melitensis biovar3 as the most prevalent serotype (Ramadan and Gafer, 2016; Hussein et al., 2019; Ramadan et al., 2019,b).

In the running study, the higher prevalence rate of isolation was observed from milk samples acting a great public health significance and considered as a particularly serious hazard (ElSayed et al., 2011,b; Ibrahim et al., 2012). Furthermore, the highest rate of isolation was remarked from goat' samples (milk and vaginal) accomplishing this animal as the main source of re-emerging the disease not only in the sheep and goat flocks, but also in the large ruminants, however, Egypt has mixed populations of sheep, goats, cattle, and buffaloes (Samaha et al., 2008). In addition to Abd El-Fatah et al. (2014) recorded that the isolation rate was $100 \%$ from the milk of aborted does. Moreover, Ibrahim et al. (2012) recovered $B$. melitensis DNA from the milk of cattle, buffaloes, sheep, and goats in Menufiya, Gharbia, Behira, Fayoum, Aswan, Beni-Suef, and Sohag governorates.

High prevalence of brucellosis particularly in villages with very high seropositives showed a high tendency risk for transmission to humans and animals alike (Jackson et al., 2007). In the present study, isolation of Brucella from human in contact to infected sheep and goat clarified the risk of developing of brucellosis in human which was attributed to poor animal handling practices or close animal contact and consumption of unpasteurized milk from these animals (Afifi et al 2005; Kavi et al. 2015). Besides, Havelaar et al. (2015) mentioned that Brucella spp. considered as invasive disease agents and hazardous and their outcomes included in food borne disease in human. On the other hand, others reported that approximately more than half a million new infected cases of human brucellosis that was primarily an occupational disease were affecting persons in close contact with infected animals. (Kelkay et al., 2017).

It is worth mentioning that two isolates (14.3\%) were recovered from ram' preputial swabs and identified as B. melitensis biovar3. This finding considered rams act as chronic carriers and hazardous threads playing an important role in spreading the infection especially who giving their males for fertilization of other flocks. (Hegazy et al., 2016; Nagati and Hassan, 2016).

\section{CONCLUSION}

In Egypt, brucellosis is still an endemic disease and one of the most economically devastating diseases for animal and human. The high prevalence of brucellosis in Minia governorate considered it as an epidemic area with this disease. Urgent needs of effective programs for the control of brucellosis in infected and reservoir animals, raising awareness between whose in contact with animals especially sheep and goat, and educational programs to those sharing in milk byproduct production and handling are required. A collaboration between public health and veterinary medical managements should be applied to train the physicians and the veterinarians for increasing the health awareness of people especially in rural community. Further studies on 
brucellosis should be conducted in other areas for setting up priorities for control measures.

\section{Acknowledgment}

The authors would like to thank all staff of Directorate of veterinary medicine, veterinarians and assistants in Minia for their intimate cooperation in collecting sheep and goat samples. Also, we are greatly thankful to doctors and nurses of Health Insurance clinic in Minia for their helpful aids in drawing the human blood samples. Finally, we are grateful to the animal owners for their helpful cooperation for completing this study.

\section{REFERENCES}

Abd El-Fatah, F.E., Abd El-Tawab, A.A. and Khoudair, R.M. (2014): Evaluation of some serological techniques used for diagnosis of Brucella in sheep and goat. M. V. Sc., Thesis, Fac.Vet. Med., Benha University.

Afifi, S., Earhart, K., Azab, M.A., Youssef, F.G., El Sakka, H., Wasfy, M., Mansour, H., El Oun, S., Rakha, M. and Mahoney, F. (2005): Hospital-based surveillance for acute febrile illness in Egypt: a focus on community-acquired blood stream infections. Am. J. Trop. Med. Hyg. 73(2). 392-399.

Alton, G.G., Jones, L.M., Angus, R.D. and Verger, J.M. (1988): Techniques for the Brucellosis Laboratory Institute National De Le Recherche Agronomique. (INRA) Publications, Paris, France. 17-60.

Bricker, B.J. and Halling, S.M. (1994): Differentiation of Brucella abortus bv. 1, 2, and 4, Brucella melitensis, Brucella ovis, and Brucella suisbv. 1 by PCR. J. Clin. Microbiol., 32, 26602666.

Colmenero, J.D.1.; Morata, P.; Ruiz-Mesa, J.D.; Bautista, D.; Bermúdez, P.; Bravo, M.J. and Queipo-Ortuño, M.I. (2010): Multiplex real-time polymerase chain reaction: a practical approach for rapid diagnosis of tuberculous and brucellar vertebral osteomyelitis.; 35(24): E1392-
1396.

Corbel, M.J. (1997): Brucellosis: an overview. Emergency Infection Diseases, 3:21321.

Corbel, M.J. (2006): Brucellosis in humans and animals. Geneva, Switzerland: WHO press - World Health Organization (WHO/CDS/EPR/2006.7) produced by the World Health Organization in collaboration with the food and agriculture Organisation of the United Nations and World Organization for animal health.

Ekgatat, M., Kanitpun, R., Khunchit, P., Arampong, W., Raksajit, S., Thammasart, S., Trenuntawan, U. and Tumcha, P. (2010): Comparison of serological tests for antibody detection against Brucella melitensis infection in goats. J. K. V. 20: 19-26.

El-Diasty, M.M., Wareth, G., Melzer, F., Mustafa, S., Sprague, L.D. and Neubauer, H. (2018): Isolation of Brucella abortus and Brucella melitensis from seronegative cows is a serious impediment in brucellosis control. Vet Sci. 5(1): 28.

El-Diasty, M.M.; Ahmed, H.A.; Sayour, A.E.; El Hofy, F.I.; Tahoun, A.B. and Shafik, S.M. (2016): Seroprevalence of Brucella spp. in Cattle, Molecular Characterization in Milk, and the Analysis of Associated Risk Factors with Seroprevalence in Humans, Egypt. Vector Borne Zoonotic Dis.; 16 (12):758-764.

Elfaki, M.G., Al-Hokail, A., Nakeeb, S.M. and Al-Rabiah, F.A. (2005): Evaluation of culture, tube agglutination, and PCR methods for the diagnosis of brucellosis in humans. International Medical Journal of Experimental and Clinical Research. 11(11). 69-74.

EL-Sayed, M., El-Newishy, A., Hussein, M., EL-Ged, A., EL-Basionny, A. and ELOlamy, G. (2011, a): Serological studies of man and animal brucellosis in Sharkia governorate. Benha Veterinary Medical Journal, II (Special Issue): 2335.

El-Sayed, M.E.M., El-Newishy, A.M.A., Hussein, M.H., EL-Ged, A.M.S.; El- 
Basionny, A.A. and El-Olamy, G.M. (2011, b): Public hazard of Brucella microorganisms in milk and dairy products and survival of Brucella melitensis biovar 3 in old Cheese. Benha Veterinary Medical Journal. (Special Issue): 35-41.

Fadeel, A. Wasfy, O. Pimentel, G. Klena, D. Mahoney, J. and Hajjeh, A. (2006): Rapid ELISA for the diagnosis of human brucellosis in surveillance and clinical settings in Egypt. Saudi Med. 27 (7): $975-981$.

Farghaly, R.M., Amer, S.A., Fahim, A.E., Kishk, R.M. and Abbas, M.F. (2018): Predictors of brucellosis seropositivity among exposed workers. Egyptian Journal of Occupational Medicine. 42 (2): 209-226.

Havelaar, A.H., Kirk, M.D., Torgerson, P.R., Gibb, H.J., Hald, T., Lake, R.J., Praet, N., Bellinger, D.C., de Silva, N.R., Gargouri, N., Speybroeck, N., Cawthorne, A., Mathers, C., Stein, C., Angulo, F.J. and Devleesschauwer, B. (2015): World Health Organization Foodborne Disease Burden Epidemiology Reference, G., 2015. World Health Organization global estimates and regional comparisons of the burden of foodborne disease in 2010, PLoS medicine, 12, e1001923.

Hegazy, Y.M., Elmonir, W., Abdel-Hamid, N.H. and Elbauomy, E.M. (2016): Seroprevalence and "Knowledge, Attitudes and Practices" (KAPs) survey of endemic ovine brucellosis in Egypt. Acta Vet. Scand., 58:1.

Hegazy, Y.M., Moawad, A., Osman, S., Ridler, A. and Guitian, J. (2011): Ruminant brucellosis in the Kafr El Sheikh Governorate of the Nile Delta, Egypt: prevalence of a neglected zoonosis. PLoS Negl. Trop. Dis. 11; 5(1):944.

Hussein, A.H., Mohamed, R.H., Abdel-Ra'ouf, M.A., Abu-Elnag, E.M.E., Mohamed, S.R., Hussein, E.A. and Wehrend, A. (2019): Diagnosis of Brucellosis in recently aborted ewes using serological tests and polymerase chain reaction. J. Applied Sci., 19: 77-81.

Ibrahim, A.K.; Abdelall, A.A. and Amin, A.S.
(2012): Long term diagnostic studies for detection of Brucella spp. in milk samples. Global Veterinaria. 8(1): 54-61. Jackson, R., Ward, D., Kennard, R., Amirbekov, M., Stack, J., Amanfu, W., El-Idrissi, A. and Otto, H. (2007): Survey of the seroprevalence of brucellosis in ruminants in Tajikistan. Veterinary Record.161: 476-482.

Kavi1, A., Shivamallappa, S.M., Metgud, S.C. and Patil V.D. (2015): An epidemiological study of brucellosis in rural area of North Karnataka. International Journal of Medical Science and Public Health. 4 (9):11971201.

Kelkay, M. Z., Gugsa, G., Hagos, Y. and Taddelle, H. (2017): Sero-prevalence and associated risk factors for Brucella sero-positivity among small ruminants in Tselemti districts, Northern Ethiopia. Journal of Veterinary Medicine and Animal Health, 9 (11): 320-326.

Kumar, V.G.; Shivasharanappa, N.; Amit, K.; Kumaresan, G.; Ashok, K. and Rajveer, S.P. (2014): Markers for the molecular diagnosis of brucellosis in animals. Advances in Animal and Veterinary Science 2 (3s): 31-39.

MacMillan, A.P. (1990): Conventional serological tests. In: K. Nielsen, J.R. Duncan, (Eds.), Animal Brucellosis. CRC Press, Boca Raton, Florida, pp: 153-197.

Montasser, A.M., Affi, M.M., El-Bayoumy, E.M., Abdul-Raouf, U.M. and Mohamad, H.A. (2011): Efficiency of Serological Tests for Detection of Brucellosis in Ruminant at South Provinces of Egypt. Global Veterinaria. 6 (2): 156-161.

Mukherjee, F.; Jain, J.; Patel, V. and Mrinalini, N. (2007): Multiple genus-specific markers in PCR assays improve the specificity and sensitivity of diagnosis of brucellosis in field animals. Journal of Medical Microbiology 56, 13091316.

Nagati, S. F. and Hassan, S.K. (2016): Diagnosis of Brucella Infection in Sheep and Goat and Evaluation of the 
associated Practices in Animal Contacts. American Journal of Infectious Diseases and Microbiology. 4 (5): 95101.

Nicoletti, P. (1990): Vaccination against Brucella. Advanced Biotechnological Processes, 13:147-168.

OIE (2009): Ch. 2.4.3. Bovine brucellosis. In: Manual of diagnostic tests and vaccines for terrestrial animals, pp. 624-659. OIE, Paris, France.

OIE (2015): Principles and methods for the validation of diagnostic tests for infectious diseases in wildlife. In: OIE manual of diagnostic tests and vaccines for terrestrial animals. Office International des Epizooties, Paris, France, pp. 1-7.

OIE (2016): Brucellosis (Brucella abortus, $B$. melitensis and B. suis) (Infection with $B$. abortus, B. melitensis and B. suis. Terrestrial manual. Chapter 2.1.4.

Ramadan, E. S., Mousa, W.A., Gafer, J.A., Elbaz, H.T., Abdeen, E. and Hussien, H. $(2019, b)$ : Substantial virulence genes among Brucella melitensis field strains isolated from cattle in Egypt. Pak. J. Biol. Sci., 22: 239-246.

Ramadan, E.S. and Gafer, J.A. (2016): Comparative conventional and molecular tools for detection and differentiation of Brucella field and vaccinal strains. Assiut Vet. Med. J. 62 (148):13-23.

Ramadan, E.S., Ali, A.H., El-Tantawy, L.A., and Ibrahim, I.G. (2019, a): Effect of serum treatment with chloroform on increasing specificity of rose Bengal test for diagnosis of brucellosis. AJVS. 61 (2): 32-37.
Ramadan, E.S., Nassar, N.R., Ibrahim, I.G. and Zayed A.F. (2019,c): Epidemiological and zoonotic surveillance of brucellosis in Beni-Suef governorate. AJVS. 61 (1):33-31.

Ramadan, E.S.; Abou-Gazia, K.A. and Ibrahim, I.G.A. (2014): Seroprevalence of brucellosis among suspected case of camels. J. Egypt. Vet. Med. Assoc. 74 (2): 293-303. Proceedings of the 30th Arab Vet. Med. Congress, May 12-14 (2014), Cairo, Egypt.

Safaa, E.E. (2011): Serological tests on caprine brucellosis. M. V. Sc., Thesis, Fac. Vet. Med., Alex. University.

Samaha, H., Mohamed, T.R., Khoudair, R.M. and Ashour, H.M, (2009): Serodiagnosis of brucellosis in cattle and humans in Egypt. Immunobiology J. 214.223-226.

Samaha, H., Al-Rowaily, M., Khoudair, R.M., Ashour, H.M. (2008): Multicenter study of brucellosis in Egypt. Emerg. Infect. Dis. 14(12):1916-1918.

Sambrook, J., Fritsch, E.F. and Maniatis, T. (1989): Molecular cloning: A laboratory manual. Cold Spring Harbor Lab., Cold Spring Harbor, N.Y.

Thakur, S.D.; Thapliyal, D.C. and Kumar, M. (2003). Current status of sero-diagnosis of brucellosis. J. Immunol. Immunopathol. 5(1): 12-26.

Wareth, G., Hikal, A., Refai, M., Melzer, F., Roesler, U. and Neubauer, H. (2014): Animal brucellosis in Egypt. The Journal of Infection in Developing Countries. 8, 1365-1373. 